\title{
The Barrier and Strategy of Higher Education in Developing Human Resources
}

\author{
Muhammad Zakiy \\ Universitas Muhammadiyah Yogyakarta \\ zakiy_ishak@yahoo.com
}

\begin{abstract}
The purpose of this study is to find out the characteristics of human resources, the barriers and strategies of college in developing human resource. This is a library research. The results of this study are a). Characteristics of human resources are: (1) kafa'ah, (2) himmatul-'amal, (3) amanah; b). The obstacles faced by college, both Islamic and public universities as producers of sharia-based human resources are the limitations of Islamic finance economists who comprehensively master financial economics and sharia sciences, the limitations of shariabased teaching curriculum, the lack of textbooks on sharia economics, no linkage with sharia financial institutions and limited funds so research on sharia economy is still very limited; (c). The strategies that can be done by universities are: looking for qualified human resources, having good intangible asset and quality system and organizational support. From these strategies, it is expected that college can contribute by providing qualified practitioners and academicians of sharia economic.
\end{abstract}

Keywords: obstacles; strategy; college; human resources

\begin{abstract}
Abstrak
Tujuan penelitian ini adalah untuk mengetahui karakteristik Sumber Daya Insani (SDI), Hambatan perguruan tinggi dalam mengembangkan SDI, dan strategi perguruan tinggi dalam mengembangkan SDI. Penelitian ini menggunakan pendekatan library research. Hasil penelitian ini adalah a). Karakteristik dari SDI adalah Sumber Daya Manusia (SDM) yang bercirikan tiga hal, yaitu: (1) kafa'ah, (2) himmatul- 'amal, (3) amanah; b). Hambatan yang dihadapi perguruan tinggi baik PTAI (perguruan Tinggi Agama Islam) maupun umum sebagai penyedia SDI berbasis ekonomi syariah adalah keterbatasan ahli ekonomi keuangan Islam yang menguasai secara komprehensif ekonomi keuangan dan ilmu syariah, keterbatasan segi kurikulum pengajaran yang berbasis syariah, kurangnya buku teks tentang ekonomi syariah, belum adanya linkage dengan lembaga keuangan syariah dan keterbatasan dana sehingga riset tentang ekonomi syariah masih sangat terbatas; (c). Strategi yang dapat ditempuh oleh perguruan tinggi antara lain: mencari bibit unggul, memiliki intangible asset yang baik dan memiliki kualitas sistem dan dukungan organisasi yang baik. Dari kedua strategi tersebut, diharapkan perguruan tinggi dapat memberikan kontribusi dengan melahirkan para praktisi dan akademisi ekonomi syariah yang berkualitas.
\end{abstract}

Kata Kunci: hambatan; strategi; perguruan tinggi; SDI 


\section{INTRODUCTION}

A research conducted by McKinsey (2012) in several countries including Indonesia projected that it will emerge groups that have middle-up income in Indonesia in 2030. This makes financial institutions increase. McKinsey's research results have given positive impacts on the banking industry, especially sharia banking which is growing rapidly in Indonesia. The high public interest in economy and Islamic banking encourages many universities to open the major of sharia banking. Munthe (2012) said that the need for Islamic banking human resources is 24,531 people per year and is predicted to reach 179,646 people by 2020 .

The rapid development of the Islamic finance and banking industry now requires qualified human resources that are capable of knowing the conceptual level as well as the application of economics and sharia banking. The development of economic and sharia banking in its various aspects needs qualified human resources in maintaining and continuing the existence of Islamic economics in the world. The government support which is getting better and accommodative for the development of sharia banking and economic practices, especially with the introduction of the Sharia Banking Law and the State Sharia Securities Law in 2008, gives a brighter new hope for the future of economic and sharia banking practices in Indonesia. Therefore, the availability of qualified human resources that support the development and expansion of Islamic economics practices in Indonesia is a necessity (Kholis, 2008). Based on statistic data of sharia banking of Bank of Indonesia (BI), in October 2013, total number of human resources of sharia banking industry was 42,062 people, consisting of 26,514 employees of Sharia Bank, 10,722 Sharia Business Unit employees, and 4,826 employees of Sharia Rural Banks (Istikhomah, 2014)

According to Wahyu Dwi Agung (former chairman of Asbisindo) and Syakir Sula, currently it's only $10 \%$ of human resources that have sharia backgrounds working in the Islamic finance industry and $90 \%$ are human resources with conventional backgrounds that are orbited through short sharia banking training. This is reinforced by the research conducted by the University of Indonesia on human resource in Islamic banks. According to Harisman (Director of Sharia Banking Directorate), in the next 4-5 years it needs 10 thousand employees to fill the sharia banking industry in Indonesia. Bank of Indonesia's data says that it is even higher namely 14 thousand employees are needed to fill the sharia banking industry throughout Indonesia (Amalia \& Al Arif, in Istikhomah, 2014).

The large demand for human resources of economy and sharia banking requires universities to create competent graduates of economics and Islamic banking. Shaping a competent sharia economic and banking scholar should be done by universities, since the selection held by sharia banks in choosing bank employees is not only derived from sharia banks only, but conventional economics and banking scholars can also follow the selection held by Islamic Bank. In line with research by Munthe (2012) who found that many human resources in sharia banking coming from general majors are given sharia banking training. This is done because the bank does not want to take risks by limiting its employees from sharia economics and banks only. Seeing the potential of qualified human resource from other majors is very large, so the sharia banks do not require employees that they must come from the department of economics and sharia banking. Therefore, creating highly competitive Islamic banking scholars is undertaken 
by universities in Indonesia.

Many universities in Indonesia have created scholars of economics and sharia banking, but they must still compete with other scholars graduating from conventional economics major. In addition, the sharia banks also have not established a special cooperation with universities in the recruitment of human resources at Sharia Banking. This is proven by data in the field that Islamic economics graduates at Islamic banking are still view (Munthe, 2012).

This condition is a challenge that can motivate the next generation to undertake the development of economics higher education and sharia banking. Islamic universities both public and private have the same opportunity to hold institutional development, establishing faculty/department of Islamic economics with various study programs tailored to the needs of sharia banking market. Therefore, the institutional development of these universities will not be successful if they do not cooperate with the government (in this case is Diknas and Depag), which usually involves administrative matters, such as permits; banking world (as a user); and college (as the organizer). These three components must work together so that output is good and beneficial to the progress of the nation, especially the Islamic economy (Asnaini, 2008).

The opening of sharia banking opportunities to develop in the future has also given the opportunity for universities, since along with the increase of sharia banks; the need for Human Resources will also increase. This phenomenon is a great opportunity for universities in fulfilling human resources at sharia bank. Human resources who graduate from economics and sharia banking should be more established in filling the strategic position at sharia bank. Graduates of economics and sharia banking have mastered the basic and applied sciences related to sharia bank. Therefore, the graduates are qualified enough to work.

However, these opportunities are also a challenge for economics and sharia banking graduates, because sharia bank accepts the employees who graduate not only from sharia banking major but from various educational backgrounds. There has not been rule that the employees of sharia bank are graduates of sharia banking major. There is no regulation or policy because sharia banks have not been fully convinced of the capability of graduates of economics and sharia banking. These opportunities and challenges become the center of attention for the university's organizers. To answer these opportunities and challenges, the college needs to develop strategies in competing.

\section{METHODOLOGY}

The type of research used in this paper is a library research or literature study obtained from several sources that are considered to support the theme of this paper. Methods of collecting data used in this research are: (1) Library Studies. This method is used to explore the theoretical basics associated with university strategy in developing human resources; (2) Observation. The data obtained from various sources was observed and analyzed in relation to university strategy in developing human resources (Trimulato, 2017). 


\section{DISCUSSION}

\section{Characteristics of Sharia-based Human Resource}

The characteristics of sharia-based human resources are: (1). Kafa' $a$ h, which means proficient or expert in the field of work performed; (2). Himmatul-'amal, which means having high motivation to work; (3). Amanah, which means responsible and reliable on carrying out every duty or obligation (Rukiah, 2015). These three characteristics of human resources become the foundation to formulate the output of universities in formulating human resource education.

\section{Islamic Economics Education in Indonesia}

Nowadays, the pattern of development of Islamic economics education at universities in Indonesia is quite different. Research conducted by Amalia \& Al Arif (2013) showed the existence of 2 institutional trends of Islamic economics education. First, the establishment of departments that brings the specific nomenclature of Islamic economics. Second, the formation of high school specializing in the study of Islamic economics.

The Results of the research showed the maps of the structure of Islamic economic education at the State Islamic University/IAIN, private Islamic colleges and public universities in Indonesia. private Islamic collages and public universities in Indonesia and the number of universities that open sharia economics major is still limited. There is only a view big university that have opened the program of Islamic studies, it is just Islamic economics courses with some credits.

\section{Barriers of Higher Education in Developing Human Resources}

Higher education that produces human resources based on sharia economy is still difficult. Related to this, Edwin (in Munthe, 2012) stated that there are five things that become obstacles in conducting Islamic economics education in Indonesia.

1. Limitations of Islamic finance economists who comprehensively master financial economics and sharia sciences. Islamic economics can be said to be new when compared with conventional economics, so the science of sharia economy is still widely taken from the sciences in economics in general. As a result, the understanding of sharia economy in Islamic banking does not get attention and has not become a benchmark for the success of sharia banking.

2. Limitations of the sharia-based curriculum. The majority of subjects taught in universities are still general, so the process of deepening Islamic economics has not been optimal. And students' understanding of sharia economy is not deep enough, so they cannot be said as an expert in sharia economy.

3. Still lack of textbook on sharia economy. The development of science in the field of Islamic economics in Indonesia is relatively slow compared to other Islamic countries such as Malaysia, Bahrain and Qatar. This might cause the lack of pure textbooks written in Indonesian language that discusses the condition of sharia economy in Indonesia.

4. There has not been linkage with sharia financial institutions. As the previous authors have noted, the integration between sharia economic institutions and Islamic financial institutions must be done in order to benefit both parties. 
5. Limited funds, so research on sharia economy is still very limited.

The existence of these obstacles will certainly hamper the development of higher education to produce human resources based on sharia economy as expected.

\section{High Education Strategy in Developing Human Resources}

Many strategies are done both by companies and institutions in improving their competitiveness. Strategies such as the formulation of vision and mission, educational goals, the determination of courses taught and banking practices have become something that must be done. However, if all educational institutions do so, then economic and sharia banking graduates will have the same competitiveness as other institutions. In the end, the bachelor of economics and sharia banking must struggle to face scholars from other majors to get a job in sharia banking. Therefore, special strategies are needed for the scholars of economics and sharia banking to have the advantage in competing with scholars from other majors. Here are some strategies that should be done by the college organizers:

\section{Looking for Superior Student Candidate}

To find a qualified student candidate, the college must know the function of the student selection itself. Students who are able to pass the predetermined selection standard is the first step to get a qualified student candidate. The standards for graduating to become economics students and sharia banks must also be high in order to produce the best students. Unfortunately, in some universities, the student's graduation standard is still very low, so becoming an economics student is the last option to continue the study. In other words, students of Sharia institution or faculty of economics do not undertake strict selection. This makes the sharia economics students have a difference in quality that is too big. Students who have very low selection scores and those who have a very high selection score can be in one class.

The negative impact of these quality differences can make learning process in the class less effective and efficient. Lecturers should take longer to explain that students can have the same competencies. This can make it difficult for other lecturers and students to deliver materials considering that the higher education curriculum system requires graduates to have the same competencies. In addition, well-motivated students may also be affected by students with low ability. This is in accordance with social learning theory from Bandura which says that the motivation and character of a person can be influenced by the surrounding environment (Robin \& Judge 2013). The decrease in motivation for reaching achievement from other students can also be explained by the Equity Theory of Adams (1963) which says that when a person gets an appreciation (in this case a value) is equal to another person whose performance is worse than that, the person will either protest or decrease performance to match the award given to them.

To avoid such a negative effect, the college must increase the standard of graduation and select students of sharia economics seriously. The improvement of this passing standard can be done gradually in line with the improvement of existing systems within the institution. With a good system, it will attract students to become part of the institution. Vianen, Shen, \& Chuang (2011) explain that the suitability of applicants with organizations or institutions can increase employees' commitment to the company. It can be said that students who choose economics and sharia banking majors as the 
main choice to continue their education in college are more committed to learning than students who choose economic institutions and sharia banking as the last option.

With such a competitive student admissions system, universities will get more qualified students. This opinion is promoted by Holtbrugge, Friedmann, \& Puck (2010) in their research that they found that internal recruitment positively affects the quality of job applicants in European companies residing in India. Referring to the goal-setting theory of Locke which says that more difficult and specific goals will improve one's performance (in Robin \& Judge, 2013). This means that strict screening and high passing grade standards will elevate students' motivation in learning and striving to pass the passing standards. The objective of such strict selection is to familiarize the students in order to give their ability optimally.

In addition to selecting students competitively, the number of students who are accepted must also be maintained in order to keep the reputation of universities in managing students. Too many accepted students might handicap teaching learning process and is hard to control. Some universities that have ideal number of students tend to be easily managed, so it is easy to keep teaching learning process easily and efficiently.

By having qualified students, the teaching learning process becomes easier. The function of rigorous screening, the selection of well-qualified students and the continuous control of the colleges can make this happen. By doing so, it is possible that the bachelors of economics and sharia banking will have high competitiveness, and they are able to compete with scholars from other majors. High competitiveness of bachelor in economics and sharia banking can be absorbed maximally by sharia banking. In fact, the sharia banking will establish cooperation with the institution in terms of human resources recruitment at sharia banking.

\section{Having Good Intangible Assets}

Intangible assets are an invisible asset owned by a company or institution. These assets can be human capital, knowledge, and brand owned by a company or institution. As technology and information develop, the competitiveness of a company or institution has shifted from tangible assets into intangible ones (Verbeke \& Yuan, 2013; Shaw, Park \& Kim, 2013). Nike famous for its sports shoes and Apple well-known for its smartphone do not even have their own factory, because the shoes and smartphone products are made by other vendor companies. The importance of intangible assets in determining the competitiveness of a company has attracted many experts to conduct research.

The first and most important intangible assets for an institution are human capital or qualified human resources. The role of human resources in determining the future of a company has been widely proven by empirical research (Shaw et al., 2013; Omondi et al., 2011; Becker \& Huselid, 2006). Barney (1991) has proposed the concept of Resource Based View (RBV), which explains that the competitiveness of a company can be determined by internal resources of a company such as a qualified human resource. Looking at the economics and sharia banking department which is currently developed, the human resources get involved in it. In this case the teaching staff/lecturer should be more committed to developing the department. The high commitment of lecturers who are aware of good performance can improve the competitiveness of the institution.

Ulrich (1998), explains that there are five new challenges and roles of human 
resources to enhance competitiveness:

a. Globalization. Seeing the rapid expansion of the global market, human resource is required to balance the paradox to think globally and act locally. Human resource is required to master the knowledge and information of the international world for the sake of development of companies or institutions. Globalization demands organizations to improve their ability to learn, to collaborate, and to manage diversity, complexity and ambiguity.

b. Profitability through growth. The encouragement to always grow and make a profit is a demand for a company or institution. Companies that want new customers and develop new products must create creativity and innovation. This can be created through a free information and sharing knowledge among employees. Employees are also required to be more focused on customers' need that always changes.

c. Technology. Human resources working in a company or institution are required to master the technology that develops very rapidly. By utilizing technology, it can facilitate us in working. Ideas and information that develop very quickly can be obtained through technology such as internet. Therefore, it is important for managers to choose and develop technology to improve company performance.

d. Knowledge. Knowledge is one of the determinants of company competitiveness. For that reason, every employee is required to have specific knowledge in accordance with their respective expertise. Through knowledge, the company can also differentiate the quality that it has from other companies, as well as the strategy to acquire customers. Therefore, company or institution must maintain and develop individuals who have knowledge that can improve competitiveness.

e. Change. The biggest challenge faced by any company or institution is how to adapt to changes coming continuously. With continuous change, companies must create inconvenience for employees to detect trends faster in order to compete with others. In addition, companies or institutions must also seek new strategies to face the change. In other words, the company must be in a continuous transformation change.

To face the challenges described above, it is necessary that human resources should always try to develop themselves in an organization. Human resource is also a major asset owned by a company or institution. By having qualified human resources, universities will quickly develop and be ready to face challenges. It means that by having qualified lecturers, the universities can produce economists who are ready to compete in the working world. In other words, having qualified students, if it is not balanced with good lecturers, then college will not have high competitiveness.

The second intangible assets are knowledge that can shape creativity and innovation. Companies like Microsoft, Apple, Samsung and Google are proof of the importance of knowledge playing a role in improving competitiveness. In addition, many experts have proven that creativity can increase the value of the company directly (Spanjol et al., 2015; Joo et al., 2014; Khazanchi \& Masterson, 2011). This is the reason why many companies are interested in pursuing Knowledge Management. Intangible assets are also a major factor in creating superior products and services, so it can be favoured by consumers. Human resources who have good knowledge will always think to make radical changes known as "Creative Destruction".

The last intangible asset is Brand Assets which is an economic rent of a company, 
and it is the profit obtained by the company without going through the production process. A good brand image can increase customer's loyalty, so customers will be willing to pay more in order to obtain the product or service from the company (Haumann et al., 2014; Bawa et al., 2013; Anderson \& Swaminathan, 2011). Companies like Apple, BMW and Aqua are examples that already have a brand asset that increases the value of the company. But the brand asset can be obtained if human capital and knowledge assets are in the company. In other words, a good brand will not be produced without qualified human resources. Therefore, if the college wants to improve its brand image, then the institution must improve the quality of the human resource in the institution first.

\section{Good System Quality and Organizational Support}

Barney \& Wright (1997) explain the framework of VRIO (Valuable, Rare, Imitability and Organization) which is a company strategy that can determine the future of a company. Enterprise resources that have value and skill rarely owned by another company and are difficult to imitate, if it does not get support from the organization, it will lead to unsustainable competitiveness disadvantage. That is why having qualified faculty / lecturers and students, if not balanced with good system and organizational support, the competitiveness of such educational institutions will not be high. In line with the research by Casimir et al. (2014) and Allen \& Shanock (2013) showed that organizational support to employees will increase the commitment and performance of these employees.

Blau's social exchange theory explains that a person will reciprocate the treatment of others according to how the other person treats him (Rhoades \& Eisenberger, 2002; Randall et al., 1999). Good system quality and organizational support to lecturers will improve lecturer's performance as a form of reward provided by the organization. Good system quality and support does not mean giving away what the employee wants without looking at the performance of the employee. Policymakers should be able to measure the success rate of their employees' performance in order to manage employees, because we cannot manage something if we cannot measure it.

Measuring the quality of the system and the performance of lecturers can be done by preparing the Key Performance Indicators (KPI) in accordance with the target of the institution. Employees' performance that meets the target can improve the success of sharia economics institutions. Empirical research has proved that employees' performance can improve overall company performance (Allen et al., 2013; Patel et al., 2013; Zhou et al., 2013). In addition to measuring the success of lecturers, policy holders can also measure institutional success by looking at the quality of the graduates that the institution has produced. When scholars from college are required by large companies and succeed as entrepreneurs, it can be said that the institution has succeeded in creating economics scholar. Company performance can also be measured using Balance Score Card (BSC) as promoted by Kaplan \& Norton (2000). They explain that the success of company can be measured using five indicators:

a. The financial perspective, that is how the company manages good capital and can increase its income.

b. The consumer perspective, the success of a company can be seen from how to create 
customer value that leads to customer's loyalty.

c. The internal perspective of operation/process, is how the company sells products and serves potential customers.

d. Learning and growth perspective, creating and preparing qualified human resources, so that the implementation of the strategy can run well.

Therefore, system quality and institutional support to lecturers and students should always be done by universities. Compilation of good curriculum, regular arrangement of schedules, and good financial systems can form a more conducive and effective learning environment. By creating a conducive environment, it can increase the enthusiasm of lecturers in teaching and can improve the spirit of students in learning. In addition, institutional systems and support to employees should also enhance employee's commitment and satisfaction (Stinglhamber et al, 2015). Thus, system quality and organizational support can indirectly improve the competitiveness of high education.

\section{CONCLUSION}

Sharia-based human resource can be characterized by three things, namely: (1). Kafa' $a$ h, that is proficient or expert in the field of work performed; (2). Himmatul-'amal, that is having a high spirit or work ethic; (3). Amanah, that is responsible and reliable on carrying out every task or obligation.

The obstacles faced by Islamic university are the limitations of Islamic finance economists who comprehensively master the financial economics and sharia sciences, the limitations of sharia-based curriculum, the lack of textbooks on sharia economy, the lack of linkage with Islamic financial institutions and the limitations funds, so research on sharia economy is still very limited.

Some of the strategies that can be done by universities are: looking for superior human resources, having good intangible assets and having a good quality system and organizational support. From these two strategies, it is expected that high education can contribute by producing qualified practitioners and academics of economics and sharia banking.

\section{BIBLIOGRAPHY}

Adams, J. S. (1963). Toward an understanding of inequity. Journal of Abnormal Psychology, 67, 422-436.

Allen, D. G., \& Shanock, L. R. (2013). Perceived Organizational Support and Embeddedness as Key Mechanisms Connecting Socialization Tactics to Commitment and Turnover among New Employees. Journal of Organizational Behavior, 34: 350-369.

Allen, M. R., Ericksen, J., \& Collins, C. J. (2013) Human Resource Management, Employee Exchange Relationships, and Performance in Small Businesses. Human Resource Management, 52 (2): 153-174.

Amalia, E., \& Al Arif, N. R. (2013) Kesesuaian Pembelajaran Ekonomi Islam Di Perguruan Tinggi Dengan Kebutuhan Sdm Pada Industri Keuangan Syariah Di Indonesia. Inferensi: Jurnal Penelitian Sosial Keagamaan, 7 (1).

Anderson, R. E., \& Swaminathan, S. (2011). Customer Satisfaction and Loyalty in E-Markets: A PLS Path Modeling Approach. Journal of Marketing Theory and Practice, 19 (2): 221 234. 
Asnaini. (2008). Pengembangan Mutu SDM Perbankan Syari'ah:Sebagai Upaya Pengembangan Ekonomi Islam. La-Raiba Jurnal Ekonomi Islam, 2 (1).

Badan Pusat Statistik (2016). Indikator Pasar Tenaga Kerja Indonesia Februari 2016. Subdirektorat Statistik Ketenagakerjaan. Badan Pusat Statistik.

Barney, J. B. (1991). Firm Resources and Sustained Competitive Advantage. Journal of Management, 17 (1): 99-120.

Barney, J. B., \& Wright, P. M. (1997). On Becoming a Strategic Partner: The Role of Human Resources in Gaining Competitive Advantage. Center for Advanced Human Resource Studies (CAHRS), 4 (1): 1-25.

Bawa, P., Gupta, B., \& Sharma, B. (2013). Retail Service Quality's Impact on Value Delivery \& Customer Satisfaction in a Retail Store Environment. Journal of Marketing \& Communication, 9 (1): 37-43.

Becker, B. E., \& Huselid, M. A. (2006). Strategic Human Resources Management: Where Do We Go From Here?. Journal of Management, 32 (6): 898-925.

Casimir, G., Keith Ng, Y. N., Wang, K. Y., \& Ooi, G. (2014). The Relationships amongst Leader-Member Exchange, Perceived Organizational Support, Affective Commitment, and In-Role Performance a Social-Exchange Perspective. Leadership \& Organization Development Journal, 35 (5): 366-385.

Haumann, T., Quaiser, B., Wieseke, J., \& Rese, M. (2014). Footprints in the Sands of Time: A Comparative Analysis of the Effectiveness of Customer Satisfaction and CustomerCompany Identification Over Time. Journal of Marketing, 78: 78-102.

Holtbrugge, D., Friedmann, C. B., \& Puck, J. F. (2010). Recruitment and Retention in Foreign Firms in India: A Resource-Based View. Human Resource Management, 49 (3): 439-455.

Istikhomah, N. (2014). Analisis Kinerja Sumber Daya Insani Bank Pembiayaan Rakyat Syari'ah Dana Amanah Ditinjau Dari Standar Kompetensi Kerja Nasional Indonesia. Jupe UNS, 2 (2): $109-123$.

Joo, B. K., Yang, B., \& McLean, G. N. (2014). Employee Creativity: The Effects of Perceived Learning Culture, Leader-Member Exchange Quality, Job Autonomy, and Proactivity. Human Resource Development International, 17 (3): 297-317.

Kaplan, R. S., \& Norton, D. P. (2000). Having Trouble With Your Strategy? Then Map It.Harvard Business Review, September-October: 167-176.

Khazanchi, S., \& Masterson, S. S. (2011). Who and What Is Fair Matters: A Multi-Foci Social Exchange Model of Creativity. Journal of Organizational Behavior, 32: 86-106.

Kholis, N. (2008) Ringkasan Riset Kajian Terhadap Kepatuhan Syariah dalam Praktik Pembiayaan di BMT Sleman, Yogyakarta. Fenomena: Jurnal Ilmu-Ilmu Sosial dan Humaniora, 6 (1).

McKinsey \& Company. (2012). The Evolving Indonesian Consumer. Australia: New Media Australia.

Munthe, J. G. (2012). Proyeksi Kebutuhan Sumber Daya Manusia (SDM) Perbankan Syariah dan Skenario Pemenuhannya. Magister Thesis, Universitas Indonesia.

Omondi, G. O., Magutu, P. O., Onsongo, C. O., \& Abong'O, L. A. (2011). The Adoption of Strategic Human Resource Management Practices in Commercial Banks: The Process and Challenges in Kenya. Journal of Human Resources Management Research:1-20.

Patel, P. C., Messersmith, J. G., \& Lepak, D. P. (2013). Walking the Tightrope: an Assessment of the Relationship between High-Performance Work Systems and Organizational Ambidexterity. Academy of Management Journal, 56 (5): 1420-1442.

Randall, M. L., Cropanzano, L., Bormann, C. A., \& Birjulin, A. (1999). Organizational Politics and Organizational Support as Predictors of Work Attitudes, Job Performance, and Organizational Citizenship Behavior. Journal of Organizational Behavior, 20: 159- 174.

Rhoades, L., \& Eisenberger, R. (2002). Perceived Organizational support: A Review of the Literature. Journal of Applied Psychology, 87: 698-714. 
Robbins, S. P., \& Judge, T. A. (2013). Organizational Behaviour. (Fifteenth Edition). London, Pearson.

Rukiah. (2015). Strategi Pengembangan SDM Syariah Menghadapi Pasar Global. At-Tijaroh, 1 (2): 114 .

Shaw, J. D., Park, T. Y., \& Kim, E. (2013). A Resource-Based Perspective on Human Capital Losses, HRM Investments, and Organizational Performance. Strategic Management Journal, 34: 572-589.

Spanjol, J., Tam, L., \& Tam, V. (2015). Employer-Employee Congruence in Environmental Values: An Exploration of Effects on Job Satisfaction and Creativity. Journal of Business Ethics, 130:117-130.

Stinglhamber, F., Marique, G., Caesens, G., Hanin, D., \& Zanet, F. D. (2015). The Influence of Transformational Leadership on Followers' Affective Commitment (The Role of Perceived Organizational Support and Supervisor's Organizational Embodiment). Career Development International, 20 (6): 583-603.

Trimulato. (2017). Urgensi Penerapan Calestial Management Bagi Peningkatan Kualitas SDM pada IKNB Syariah. Jurnal Ekonomi, 22 (3): 336-350.

Ulrich, D. (1998). A New Mandate for Human Resource. Harvard Business Review, JanuaryFebruary: 124-134.

Vianen, A. E. M. V., Shen, C. T., \& Chuang, A. (2011). Person-Organization and PersonSupervisor Fits: Employee Commitments in a Chinese Context. Journal of Organizational Behavior, 32: 906-926.

Verbeke, A., \& Yuan, W. (2013). The Drivers of Multinational Enterprise Subsidiary Entrepreneurship in China: A New Resource-Based View Perspective. Journal of Management Studies, 50 (2): 236-258.

Zhou, Y., Hong, Y., \& Liu, J. (2013). Internal Commitment or External Collaboration? The Impact of Human Resource Management Systems on Firm Innovation and Performance. Human Resource Management, 52 (2): 263-288. 